$\xi=$

\title{
Pteridaie: indicator of the vegetation succession and dynamics in the forests Chablis and Edges in Kahuzi-Biega National Park (Eastern D. R. Congo, Albertine Rift)
}

\author{
Mangambu Mokoso Jean De Dieu ${ }^{*}$, Ntahobavuka Habimana Honorine ${ }^{2}$, Basinyize Birhashwirwa Pascal ${ }^{3}$, \\ Lokumu Ilombelombe Lucien-Gédeon ${ }^{4}$, Robbrecht Elmar 5 \\ ${ }^{1}$ Department of Biology, Systematic Plant and Biodiversity Laboratory, Bukavu State University, D.R. Congo \\ ${ }^{2}$ Department of Biology, Service of Palynology and Biodiversity, Kisangani University, D.R. Congo \\ ${ }^{3}$ Department of Resource Management, CEPROMAD University, D.R. Congo \\ ${ }^{4}$ Congolese Institute for Nature Conservation, Kahuzi-Biega National Park, Tshivanga, D.R. Congo \\ ${ }^{5}$ National Plantentuin van België and Domain of Bouchout, Nieuwelaan / Meise, Belgium \\ *Corresponding author E-mail: mangambu2000@yahoo.fr
}

\begin{abstract}
This study was done in different forests Chablis and Edges dominated by the Pteridium aquilinum species in the mountain area of Kahuzi-Biega National Park (PNKB), eastern D.R. Congo, along the Mitumba range, in the Albertine Rift. The main goal of this study is to demonstrate the role of that patch of ferns in the recolonization of degraded areas for the forestry reconstruction and dynamics of different holes in that part of the park. The studied grouping is located at 1531 and $2452 \mathrm{~m}$ of altitude and on acid soils that root allophatic reactions related to the aptitude of roots and rhizomes of Pteridium aquilinum (L.) Kuhn. The high presence of young Phanerophytes in these sites highlights the position of the grouping in the succession and dynamics of the vegetation. The general aspect of the vegetation is dominantly herbaceous, and presented as a green mosaic in the Pteridaie. The sociological classification shows 8 different ecosociological groups (apart from non-classified) and Canonical Correspondence Analyses show that the relations between environmental variables and species are significant. The complexity of responses obtained warrants to bring more attention to forests Chablis and Edge diversity for better management and conservation of plant species.
\end{abstract}

Keywords: Pteridium Aquilinum; Plant Communities; Vegetation Succession; Forest Dynamics; Biological Traits.

\section{Introduction}

Forests play an important role in the global carbon cycle and the provision of ecosystem services (Stehman 2012). Information on where and to what extent forest disturbances occur globally is thus a crucial necessity (Patterson and Yool 1998; Baumann 2012). Remote sensing can provide accurate and timely information regarding forest disturbance in many ecoregions at scales ranging fromlocal to global and atmany different temporal resolutions (Hicke 2012; Stehman 2012; Wulder et al. 2012).

Every natural community in equilibrium has been built over long periods of time through the selection of species adapted to each other and to the abiotic environment (Patterson and Yool 1998; Alignier 2010). In normal functioning, this maintenance of the community is ensured by the replacement of dead individuals by others (De Cáceres and Legendre 2009). This phenomenon, usually referred to as regeneration, depends on the individual reproductive capacities of the species and concerns the dynamics of their populations (Vaillancourt 2008; Mangambu et al. 2010).

After the destruction of a natural community comes the phenomenon of reconstitution, which consists of a succession of communities, which can lead to a return to the original state (Patterson and Yool 1998, Peltola et al. 2000). This vegetation dynamics depends on the degree of landing of the substrate and the depth of its soil (De Cáceres and Legendre 2009; De Cáceres et al. 2010).
Thus, the natural functioning of living communities is perpetually subjected either to different constraints to dynamics by indicator species or to regression of vegetation (White, 1979; Serpantié and Devineau 1991). These indicator species give an ecological meaning to a typology of sites. They provide criteria for (i) comparing different typologies obtained by data analysis (clustering) and (ii) identifying levels of interest in a dendrogram (De Cáceres et al. 2010; Wulder et al. 2012; Legendre and Legendre 2012).

The group Pteridium aquilinum (Fig.1) is abundant in gaps at different altitudes of African highland forests, particularly at 200 to $2500 \mathrm{~m}$ (Terrestrial, in open overgrazed and degraded areas, forest and woodland edges and ericaceous scrub, Habiyaremye 1997). It is widespread in forest cores or in forests Edges (Mangambu 2013; Mangambu 2016). The dominant plant Pteridium aquilinum (L.) Kuhn (Fig. 1), (belong to the family of Dennstaedtiaceae, Van der Burg 2004, PPG I 2016).

Also called Eagle Fern, is a cosmopolitan plant with pinnate fronds approximate to distant, monomorphic; stipe adaxially sulcate; lamina pinnately compound, anadromous or catadromous, coriaceous, glabrous adaxiallyand large size, sori marginal. In tropical areas, it invades pastures, clearings, and natural highaltitude gaps and is widely distributed in the mid and high-altitude areas of Kahuzi-Biega National Park (KBNP) and its surroundings on acid soils $(p H=5.5$, Pichi-Sermoli 1985; Mangambu 2013, Mangambu 2016). 
Its expansion is favored by its single-walled spore germination (Leptosporangie), allelopathy mechanisms and aggressive rhizomes (Pichi-Sermoli 1985; Habiyaremye 1997; Van der Burg 2004; Mangambu 2013; Mangambu, 2016).

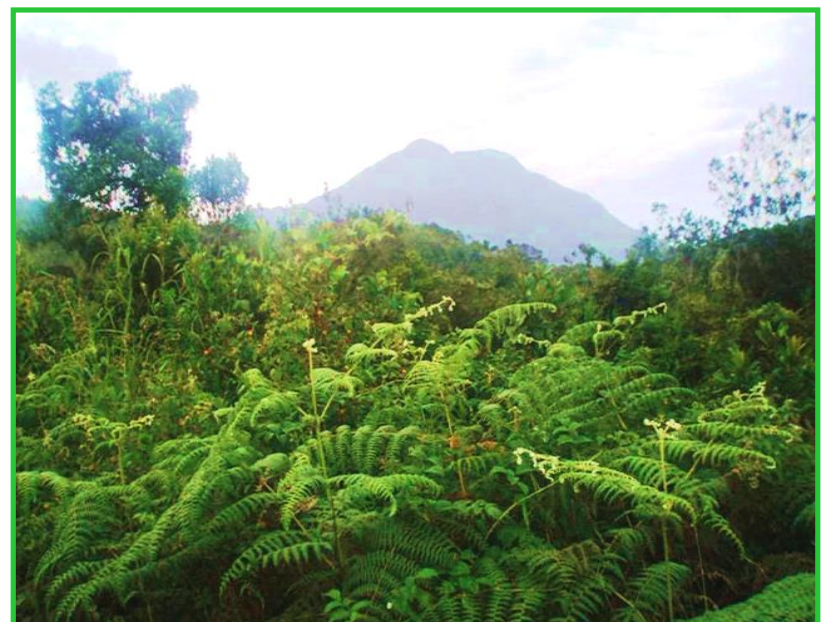

Fig. 1: General View of Pteridaie in the Forest Edge of Mugaba Station (2305 M Altitude) On the Middle Horizon of the KBNP Mountain Stage (Photo Taken By Mangambu, 2/06/2012).

The vegetation formation called "forest Edge" is a limit, a boundary portion or a specific type of boundary between two adjacent habitats that differ in one or more aspects (Forman 1995; Alignier 2010). While "Chablis" is a disturbance that is one of the natural and natural stages of the forest cycle as it unfolds in nature, which locally translates into a light gap favorable to the natural regeneration of the forest; for both grasses and young trees (De Cáceres and Legendre 2009; Alignier 2010). Edges related to forest ecology are the areas where two or more different ecological features come together, often associated with variations in the convergence of plant species. Edges are important to wildlife and offer a mix of native plants that are oftentimes found nowhere else throughout the ecosystem (Whitney 1989; Alignier 2010).

For this study, we will study the grouping with Pteridium aquilinum which dominates in these two plant formations in the medium and high altitude zones of this part of the Park and also to seek to know its role, either in dynamics or in regression vegetation. We will also examine the architecture, the physiognomy and the structure of the grouping as well as the salient physiognomic characteristics that allow the group to evolve towards a forest formation. Other points that will be addressed in this work include floristic traits, the relationship between environmental variables and the components of Pteridium aquilinum. The latter will be evaluated by the indices of diversity to determine the characteristic species that one thinks, will play a role in the floristic dynamism to replace this fougeraie

\section{Material and methods}

\subsection{Study area}

Our study is carried out in the Kahuzi-Biega National Park, with an area of $6000 \mathrm{~km}^{2}$ (Fig. 2), in its middle and high altitude floors, situated in the Albertine Rift or Africa's Western Rift Valley is one of the most biodiversity regions of the African continent (Mangambu et al. 2017; Mangambu \& van Diggelen 2017).

This Park was established in 1970 to protect eastern lowland gorillas (Gorilla beringei graueri Matschie) and their habitat (Fischer 1996). It includes two main peaks that are non-active volcanoes (extinct), the Kahuzi at an altitude of $3308 \mathrm{~m}$ and the Biega of $2790 \mathrm{~m}$, and is located in the southern part of the Kivu-Ruwenzori mountain range, NNE-SSW axis, skirting, in the west, the Albertine Rif (Webster, 1995), between the two centers of endemic Guineo-Congolese and Afro-Mountainous (Mangambu 2013).
According to their physiognomy and their floristic composition, according to the altitude (Mangambu 2016), the forests of the PNKB are differentiated in planetary stages $(678-1250 \mathrm{~m})$, submontana (1250-1700 m), mountainous (1700-2600 m) and afrosubalpine (2600-3326 m). As a whole, the study area benefits from mountain climates (such as Cf Köppen), with abundant rains oscillating between 1750-2000 millimeters per year (Mangambu, 2016). Mount Kahuzi, with nocturnal frosts, has an Afro-Alpine climate. Atmospheric humidity is constantly elevated in parallel with the change in cloud cover. The duration of the dry season does not exceed two months (Fischer 1996). The temperature varies according to the altitude, and the soil is superficial and acidic (Mangambu et al. 2013).

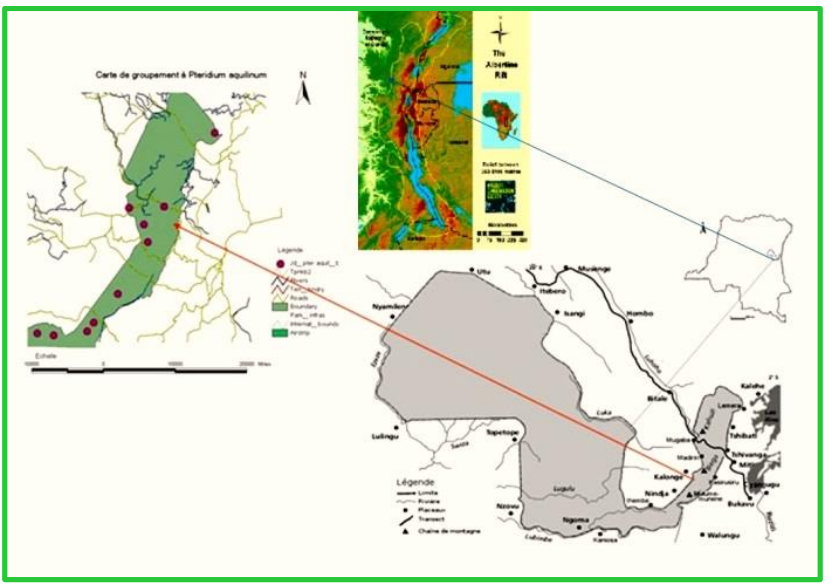

Fig. 2: Map of Kahuzi-Biega National Park (On the Right, Mangambu Et Al. 2010, Amended), and the Location of the Surveys Made in the High Altitude Part (Medium and High Altitude on the Left).

\subsection{Methodology}

\subsubsection{Sampling layout}

The sampling device consists of 10 phytosociological surveys at altitudes ranging from $1531 \mathrm{~m}$ to $2452 \mathrm{~m}$ altitude (Table 1). In the field, the directly perceptible ecological factors were mentioned as well as the geographic coordinates provided by the GPS for each survey site. The locations of the survey sites were established using GPS using the UTM system (see Table 1). In an attempt to confirm the later dynamics of the vegetation in the clusters and to indicate the scarcity of trees in the surveys, all $d b h$ "Diameter at breast height" trees and shrubs $\geq 10 \mathrm{~cm}$ were measured based on measurements of circumference taken $130 \mathrm{~cm}$ above the ground.

Table 1: Location of the Readings and Survey Area are Located in the Table Below

\begin{tabular}{|c|c|c|c|c|c|c|}
\hline \multirow[b]{2}{*}{$\mathrm{N}^{\circ}$} & \multirow{2}{*}{$\begin{array}{l}\text { Localisation } \\
\text { Toponyme }\end{array}$} & \multicolumn{3}{|c|}{ Coordinats } & \multirow[b]{2}{*}{$\begin{array}{l}\text { Area } \\
\left(\mathrm{m}^{2}\right)\end{array}$} & \multirow{2}{*}{$\begin{array}{l}\begin{array}{l}\text { Slopes } \\
\text { (degree) }\end{array}\end{array}$} \\
\hline & & Lat. & Long. & $\begin{array}{c}\text { evation } \\
(\mathrm{m})\end{array}$ & & \\
\hline 1 & $\begin{array}{l}\text { Kamosso: in a } \\
\text { north-east-east } \\
\text { direction, next to } \\
\text { the river }\end{array}$ & 643933 & 9714720 & 1531 & 324 & 5 \\
\hline 2 & $\begin{array}{l}\text { Kabona follow- } \\
\text { ing the south- } \\
\text { west orientation } \\
\text { in the middle of } \\
\text { the forest }\end{array}$ & 655051 & 9716110 & 1601 & 324 & 2 \\
\hline 3 & $\begin{array}{l}\text { Ihembe following } \\
\text { the south-west } \\
\text { orientation on the } \\
\text { mainland in the } \\
\text { middle of the } \\
\text { forest }\end{array}$ & 669384 & 9716751 & 1672 & 250 & 0 \\
\hline 4 & $\begin{array}{l}\text { Kanoiso } \\
\text { Tshivanga: in a }\end{array}$ & 680398 & 9724234 & 1478 & 250 & 0 \\
\hline 5 & $\begin{array}{l}\text { south-east direc- } \\
\text { tion near Musisi }\end{array}$ & 690110 & 97477 & 2189 & 324 & 3 \\
\hline
\end{tabular}




\section{bog}

Madiriri: follow-

ing the southwest

6 direction on the

mainland in the $\quad \begin{array}{llllll}685026 & 9742355 & 2005 & 250 & 1\end{array}$

midlle of the

forest

Madiriri: in a

7 south-east direc-

tion near Musisi

bog

Mugaba: in a

south-west

8 direction, close

to Bamboo For-

est

Kasirusiru: in a

north-easterly

9 direction, close

to the Bamboo

Forest

Lemera: Follow-

ing a South-East

direction, in the forest Edge

*Legend: Lat.: Latitude, Long. : Longitude

\subsubsection{Collection and processing of data in surveys}

For each survey, we mentioned the abundance-dominance (BraunBlanquet) of each stratum and tree and shrubby plants according to the Dufrêne scale (2005). In the phytosociological tables, we have used the frequency classes of the species (Braun-Blanquet 1932 as taken up by Senterre (2005) and Mangambu 2013, as the first criterion for classifying characteristic species of groups.

\subsubsection{Soil analysis}

We can say that plant species are sensitive to the availability of nutrients (Ballard 2000; Senterre 2005). The latter is mainly a function of the nature of the source rock and the nature of the litter. The relationship between soil $\mathbf{p H}$ and various socioecological groups using the range of acidophilic calcicole species. For each survey, five soil samples were taken in the diagonal linear sequence, four at the ends of the surface and one at the survey center (Braize 1988). The sketch of the soil characteristics is based on the determination of the state of the absorbing complex and that of the acidity of the soil. The analysis of the soil composition was done at the soil laboratory of INERA/ Mulungu (South Kivu, D.R. Congo).

The characterization of the absorbing complex was determined through the knowledge of its $\mathrm{pH}$, because the latter sometimes translates in an approximate manner the state of saturation of the soil. It is also considered variable which has been transformed into semi-quantitative code (Braize 1988).

\subsubsection{Species identification}

Field-initiated species identification was verified both by comparisons of specimens from our herbarium with reference specimens held in the herbaria of the Belgian National Botanical Garden (BR) and the Université Libre de Bruxelles (ULB). The nomenclature adopted for the different inventoried flower taxa is updated by Lebrun and Stork (1991, 1992, 1995 and 1997) and APG IV (2016). The nomenclature adopted for the different inventoried for Lycophytes and Ferns taxa is updated by and Mangambu (2013), the Pteridophyte Phylogeny Group (PPG, 2016) and Roux, 2009.

\subsubsection{Assessment of the diversity of taxa}

\section{a) Plant diversity}

Calculation of $\boldsymbol{\alpha}$-diversity was done for the following indices: Shannon Weaver, regularity of Piélou, Margalef, Menhinick and Simpson's. This makes it possible to evaluate more precisely the diversity of each grouping according to the species distribution
(Krebs1994; Magurran 2004) by the PAST software of species (Hammer et al. 2005).

The diversity- $\boldsymbol{\beta}$ indices were used to evaluate the similarity between the surveys in the two vegetation stages (Mangambu 2016). We chose the Sorensen index, which is a very simple measure of floristic similarity to compare the plant communities found in the forest windfalls ( 5 surveys) and in the selvedges ( 5 surveys). This index varies from 0 to 1.0 when there are no common species between the two surveys and 1 when the same species exist in both communities (Jacques and Christian 1983).

Indice of Sorenses $=\frac{2 \mathrm{C}}{\left(\mathrm{S}_{1}-\mathrm{S}_{2}\right)}$

Where $\mathbf{S}_{\mathbf{1}}$ is the number of species recorded in the first survey or site, $\mathbf{S}_{\mathbf{2}}$ is the number of species in the second survey or site and $\mathbf{C}$ is the number of species common to either surveys or sites.

To evaluate the role of functional groups of indicator plants, we calculated the different weight spectra by abundance-dominance. The weighted spectrum (PS) is given by the following expression (Jacques and Christian 1983):

$$
\mathrm{SP}=\frac{\sum^{\mathrm{t}}(\mathrm{RM}) \mathrm{t}}{\sum_{1}^{\mathrm{e}}(\mathrm{RM}) \mathrm{e}} \times 100
$$

$\mathbf{t}=$ Index representing (expressed in \%) the number of species having for a biological trait considered same biological type and $\mathrm{e}$ $=$ Average for all the biological traits identified in the grouping. The functional groups analyzed are: the biological types of Raunkiaer system (1934) modified by Lebrun (1947) cited by Senterre (2005), which are related to the phenological state of the species encountered and also their phytogeographic elements of White (1983 and 1986).

\section{b) Description of the structure and the physiognomy}

We have considered the description of the structure and appearance of the species in the grouping in an individual way in order to compare these entities and / or with those of other territories (Habiyaremye 1997). In order to determine the ecological affinities between the various inventoried species and to indicate the dynamic position of the grouping, we used the initials "TWINSPAN, Hill (1994)". The links between floristic and ecological variations (slope, elevation, overlap, soil $\boldsymbol{p H}$, and soil texture) were evidenced by direct Canonical Correspondance Analysis (CCA) gradients using CANOCO software. When there are few environmental variables for a large number of surveys (ter Braak and P. Šmilauer, 2002).

\section{Results}

\subsection{Floristic study and structure of the pteridium aquili- num group}

From the floristic point of view, 126 species divided into 96 genera and 59 families were harvested. The most represented families are Aspleniaceae and Asteraceae with 9 species (or 7.14\%) followed by Euphorbiaceae with 8 species (or 6.34\%); Fabaceae, Apocynaceae and Rubiaceae each have 7 species (5.55\%). Other families are less diverse.

After the biological type (Table 2 in the appendix), Phanerophytes are better represented in Pteridaie and Hemi-Cryptophytes are less generally represented in the grouping. In particular:

- In the windfall Phanerophytes are better represented with 46 species $(36.5 \%$ of the floral) which are mostly primary forest plants. It is thought that these species will play the role of this forest dynamics,

- In the surveys made in selvedges, the Phanerophytes represent only 28 species (ie $22.2 \%$ of the floral). Chamephytes come in second place with 20 species $(36.5 \%)$ of which 8 
species for windfall and $12(9.52 \%)$ because of the fact that Chamephytes, Geophytes and Therophytes are more abundance-dominance species or mean recoveries and are more observed in these forest Edge surveys.

On the basis of these results, apart from the peculiarities of each survey, the succession of species has more or less distinct physiognomic aspects and mechanisms. This succession of species of the grouping will be carried out in the following manner: Therophytes, Hemi-Cryptophytes, Chamephytes and Phanerophytes. Studies of phytogeographic distribution (Table 2 in the appendix) show that the majority of species in this group are of Afromontana endemic center, with a dominance of species with an East African mountain distribution with 27 species (21.42\%), followed by mountain species with 23 species $(18.25 \%)$. African multiregional species are present with 15 species, or $12 \%$. It should also be noted that the increase in Zambezian distribution species maintained thanks to a progressive increase in SudanoZambezian linkage species with 15 species (11.9\%).

\subsection{Determination of diversity indices}

\subsubsection{The diversity- $\alpha$ indices}

Calculation of $\alpha$-diversity was done for the following indices: Shannon Weaver, regularity of Piélou, Margalef and that of Simpson. The table below (Table 2) gives the values of these indices in the various statements as follows:

- The value of Shannon index more or less high in the surveys carried out in the forest windfall. This shows that the groupings described in this forest are more diversified in species than those of forests Edges,

- Equitability_J index, it shows a good equitability between the studied groups, because the values obtained are all high and close to 1 . Being independent of the size of the sample, the higher value is obtained in the statements being in the forest windfall,

- Margalef index: the high value obtained is found in wind throw. This demonstrates the dominance of species in forest windfall on all selvedge surveys,

- Simpson_1-D index: the values obtained show small differences between the two types of training that we carried out in our 10 surveys

- On the other hand, Menhinick index: in the windfall, the number of individuals is relatively small, but in the forests Edges, it is dominant. By comparing it (Menhinick) with that of Margalef index, we see that the two indices evolve in the same way. There is only one difference in the wind throw where Menhinick index is higher given the small number of individuals, while that of Margalef index is low (Table 2).

\subsubsection{The diversity- $\beta$ index: similarity between the surveys in forest windfalls and selvedges}

These are the Sorensen similarity coefficients discussed in this article. The results found are recorded in the histogram (Fig. 3), which shows the existence of a fairly similar similarity between the wind throw and the selvedge surveys. Nevertheless one can also show that there are very important peculiarities between the two formations which are presented how follow:

- The surveys carried out in the forest windfall (R1, R2, R5, R9 \& R10) have an important lot of the common species. Here the number of Phanerophytes is high. Most of these surveys are in the middle of the secondary forest and / or sometimes in the primary forest.
Table 2: Calculation of Mean Values of A-Diversity Indices for Each Forest Type in the Pteridaie

\begin{tabular}{|c|c|c|c|c|c|c|c|}
\hline $\begin{array}{l}\text { Re- } \\
\text { sults }\end{array}$ & $\begin{array}{l}\text { Num } \\
\text { bers } \\
\text { Ta- } \\
\text { xas }\end{array}$ & $\begin{array}{l}\text { Indi- } \\
\text { vi- } \\
\text { duals }\end{array}$ & $\begin{array}{l}\text { Shan- } \\
\text { non_H }\end{array}$ & $\begin{array}{l}\text { Equita- } \\
\text { bility_J }\end{array}$ & $\begin{array}{l}\text { Mar- } \\
\text { galef }\end{array}$ & $\begin{array}{l}\text { Simp } \\
\text { son } \\
1-D\end{array}$ & $\begin{array}{l}\text { Men- } \\
\text { hinick }\end{array}$ \\
\hline \multicolumn{8}{|c|}{ Forest Chablis } \\
\hline R1 & 73 & 1377 & $\begin{array}{l}4,25 \\
4\end{array}$ & 0,992 & 16,58 & $\begin{array}{l}0,98 \\
5\end{array}$ & 8,319 \\
\hline R2 & 53 & 957 & $\begin{array}{l}3,93 \\
7\end{array}$ & 0,992 & 12,86 & $\begin{array}{l}0,97 \\
9\end{array}$ & 7,02 \\
\hline R5 & 63 & 1467 & 4,1 & 0,99 & 14,8 & 0,98 & 7,7 \\
\hline R9 & 80 & 1084 & 4,36 & 0,99 & 17,8 & 0,99 & 8,73 \\
\hline R10 & 72 & 1180 & $\begin{array}{l}4,22 \\
6 \\
\end{array}$ & 0,988 & 16,2 & $\begin{array}{l}0,98 \\
4\end{array}$ & 8,05 \\
\hline $\begin{array}{l}\text { Ave- } \\
\text { rage }\end{array}$ & 68 & 1213 & $\begin{array}{l}4,17 \\
54 \\
\end{array}$ & 0,9904 & $\begin{array}{l}15,64 \\
8\end{array}$ & $\begin{array}{l}0,98 \\
36 \\
\end{array}$ & $\begin{array}{l}7,963 \\
8 \\
\end{array}$ \\
\hline \multicolumn{8}{|c|}{ Forests Edges } \\
\hline R3 & 41 & 1044 & $\begin{array}{l}3,65 \\
8\end{array}$ & 0,985 & 10,57 & $\begin{array}{l}0,97 \\
1\end{array}$ & 7,081 \\
\hline R4 & 53 & 1157 & $\begin{array}{l}3,90 \\
2\end{array}$ & 0,983 & 12,86 & $\begin{array}{l}0,97 \\
6\end{array}$ & 7,02 \\
\hline R6 & 59 & 1364 & 4,04 & 0,99 & 14 & 0,98 & 7,38 \\
\hline R7 & 76 & 1079 & $\begin{array}{l}4,29 \\
9\end{array}$ & 0,993 & 17,16 & $\begin{array}{l}0,98 \\
5\end{array}$ & 8,551 \\
\hline R8 & 64 & 2067 & $\begin{array}{l}4,12 \\
2\end{array}$ & 0,991 & 14,98 & $\begin{array}{l}0,98 \\
2\end{array}$ & 9,819 \\
\hline $\begin{array}{l}\text { Ave- } \\
\text { rage }\end{array}$ & 59 & 1342 & $\begin{array}{l}4,00 \\
42\end{array}$ & 0,9884 & $\begin{array}{l}13,91 \\
4\end{array}$ & $\begin{array}{l}0,97 \\
88 \\
\end{array}$ & $\begin{array}{l}7,970 \\
2\end{array}$ \\
\hline
\end{tabular}
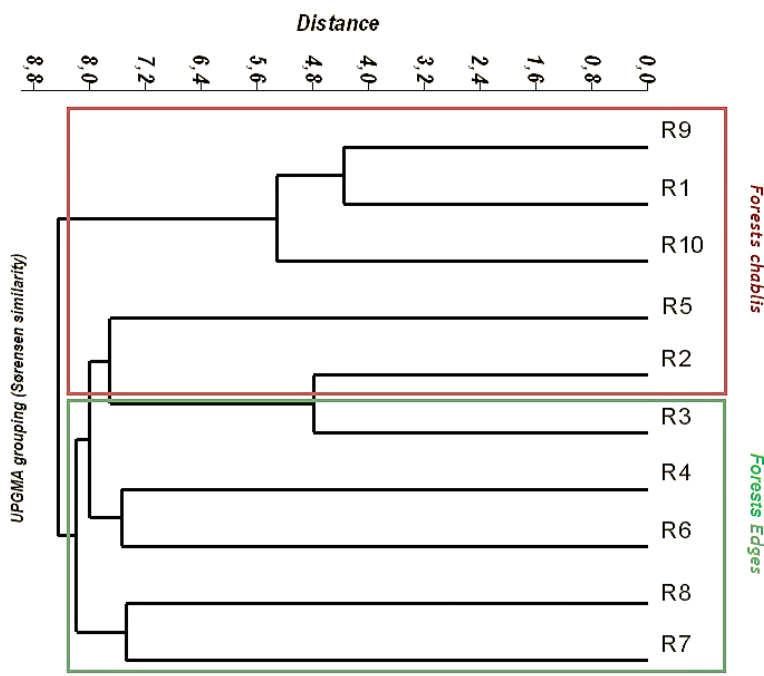

Fig. 3: Individualized Layout and Similarity between Forest and Forest Edge Surveys on A Dendrogram.

- Among these are the secondary forest species Albizia gummifera, Dombeya goetzenii, Bridelia brideliflolia, Croton megalocarpus, Harungana madagascariensis, Polyscias fulva, Harungana montana, Maesa lanceolata, Myrianthus holstii, Neobutonia macrocalyx and Tabernaemontana johnstonii, which are occasionally represented and with a very important role in forest dynamics. There is also the presence of the species of the primary rainforest forest in the undergrowth (Anthocleista grandiflora, Carapa grandiflora, Chrysophyllum gorungosanum, Dichaetanthera corymbosa, Galiniera coffeoides, Oxyanthus troupinii, Psychotria mahonii, Strombosia scheffleri and Newtonia buchananii).

- The surveys placed in the selvedges (R3, R4, R6, R7 and R8) show that the number of Chamephytes and Geophytes is high compared to Phanerophytes. It is noteworthy that these surveys have almost the same stratification present common species. Apart from lianas and herbs, the isolated presence of some Phanerophytes such as Albizia gummifera, Alchornea hirtella, Ardisia kivuensis, Chassalia subochreata, Chrysophyllum gorungosanum, Cyathea manniana, Galiniera coffeoides, Lasianthus kilimandscharicus, Mil- 
lettia dura, Oxyanthus troupinii, Pleiocarpa pycnantha, Strombosia scheffleri and Syzygium guineense. In spite of their representation, they will ensure the succession of vegetation for the installation of the forest until the stage of cli$\max$.

\subsection{Specific tree rarity in Pteridium aquilinum group records}

In general, in the surveys, the inventory of $d b h$ trees $\geq 10 \mathrm{~cm}$ were collected but with low species richness in individuals and species. There may be mentioned trees and shrubs such as Albizia gummifera, Bridelia brideliflolia, Chassalia subochreata, Dichaetanthera corymbosa, Dombeya goetzenii, Hagenia abyssinica, Harungana madagascariensis, Galiniera coffeoides, Maesa lanceolata, Myrianthus holstii, Neobutonia macrocalyx, Oxyanthus troupinii, Pauridiantha paucinervis, Polyscias fulva, Psychotria mahonii, Strombosia scheffleri and Tabernaemontana johnstonii. We can also mention the presence of some lianas that have this $d b h \geq 10$ $\mathrm{cm}$ : Gouania longispicata, Gynura ruwenzoriensis, Schefflera goetzenii and Sericostachys scandens. The majority of species are characteristic plants of mountain forests.

In a particular way:

- Forest windfall surveys (R1, R2, R5, R9 \& R10) show that the number of shrubs is high and all mentioned in the paragraph above. This is explained by the fact that most of these surveys are in the middle of secondary and / or primary forest.

- For the surveys placed in the selvedges (R3, R4, R6, R7 \& R8) we found the following species Albizia gummifera, Bridelia brideliflolia, Carapa grandiflora, Chassalia subochreata, Dombeya goetzenii, Galiniera coffeoides, Harungana madagascariensis, Maesa lanceolata, Myrianthus holstii, Neoboutonia macrocalyx, Oxyanthus troupinii and Polyscias fulva and lianas as: Gouania longispicata, Gynura ruwenzoriensis, Schefflera goetzenii and Sericostachys scandens.

The results obtained show that the rarity curves of family-specific arithmetic coordinates (Fig. 4) have a globally regular shape and obey distributions of type " $\mathrm{Y}=\mathrm{a} \mathrm{Xn}$ ". The regression is also very good with regression coefficients in all cases high and significant ( $p$ <0.001). Thus, more pronounced planarization of the curves has been observed, especially in large diameter classes. This shows that in this grouping, if we calculate the diameter classes, we will find only one. These results confirm by the rarefaction curves (Fig. 4) that they were explained by the absence of dominated trees in the large diameter classes within this group with Pteridium aquilinum on all the surveys.

Given the size of the group and the juvenile state of these species, it is likely that it will change to become a clearing. But, seeing the various species composed of shrubs forming different forest formations; primary islands with secondary forests, this group will undergo a succession of secondary forest with so-called climax formation.

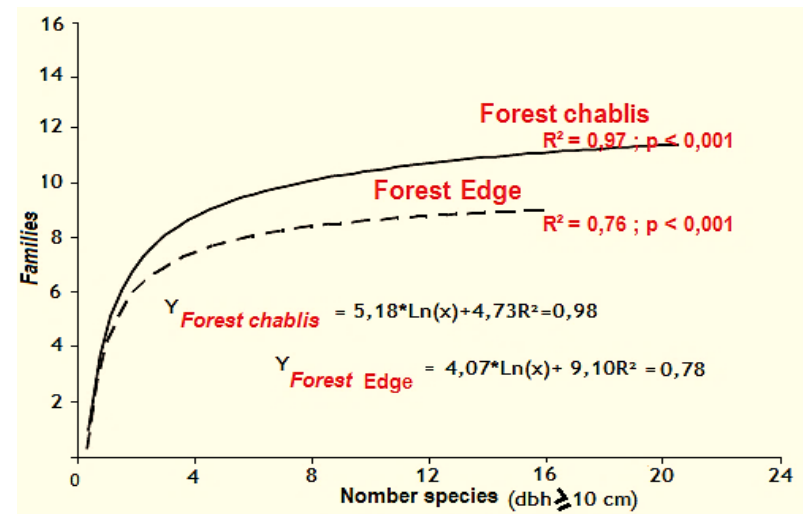

Fig. 4: Curves of Rarefaction of Species-Specific Richness in the Inventory of Species in the Surveys.

\subsection{Ecosociological groups, architecture, grouping physiognomy}

\subsubsection{Floristic procession of the group}

These harvested species form an overall floristic procession and have been classified according to their respective affinities in ecosociological groups (Table 3 below). If we rely solely on the composition of 12 ecosociological groups (plus the vascular epiphytic species and unclassified species) highlighted after the detailed analyzes in the phytosociological and the synthetic table of the group floristic procession, we find that the majority of species are in the Polyscietalia fulvae Order with 25 species (19.84\%). They are followed by species of the Strombosio-Parinarietea Class with 24 species (19.4\%). Species of the Musango-Terminalietea Class and Ficalhoo-Podocarpetalia Order. Species are represented by each of 10 species $(7.93 \%$ of their total proportion). The other groups are less represented. The high percentages of the species Polyscietalia fulvae order, Strombosio-Parinarietea Class, $\mathrm{Mu}$ sango-Terminalietea Class and those of the FicalhooPodocarpetalia Order confirm a forthcoming return of the forest in these environments dominated by Pteridium aquilinum. So this confirms that these species will play a major role in the plant succession process

Table 3: Floristic Grouping of the Grouping According to the Ecosociologicals Groups

\begin{tabular}{lll}
\hline Ecosociologicals groups & Species & $\%$ \\
& Number & \\
\hline Polyscietalia fulvae Order & 26 & 19,84 \\
Strombosio- Parinarietea Class & 24 & 19,05 \\
Musango - Terminalietea Class & 10 & 7,937 \\
Ficalhoo - Podocarpetalia Order & 10 & 7,937 \\
Ruderali - Manihotetea Class & 9 & 7,143 \\
Soncho - Bidententntea Class & 9 & 7,143 \\
Mitragynetea Class & 8 & 6,349 \\
Epiphytics species & 8 & 6,349 \\
Hyparrhernietea Class & 6 & 4,762 \\
Unclassified Species & 6 & 4,762 \\
Oleo - Jasminetalia Order & 5 & 3,968 \\
Bidentetalia Pilosae Order & 2 & 1,587 \\
Lycopodietea cernuii Class & 2 & 1,587 \\
Sphagno - Xyridetelia Order & 1 & 0,794 \\
\hline Total & 126 & 100 \\
\hline
\end{tabular}

\subsubsection{Architecture, physiognomy and structure of the group}

The grouping is dominated by the herbaceous layer, dense and lush green. There are also trees and shrubs (5 to $12 \mathrm{~m}$ high). We can cite: Albizia gummifera, Bridelia brideliflolia, Chassalia subochreata, Dombeya goetzenii, Hagenia abyssinica, Harungana madagascariensis, Galiniera coffeoides, Maesa lanceolata, Myrianthus holstii, Neobutonia macrocalyx, Oxyanthus troupinii, Pauridiantha paucinervis, Polyscias fulva, Psychotria mahonii, Strombosia scheffleri and Tabernaemontana johnstonii.

- There are also some lianas that reach the tree layer (Gouania longispicata, Gynura ruwezoriensis, Mikania capensis, Mikania cordata, Schefflera goetzenii, Sericostachys scandens and Urera sp.) as well as some vascular epiphytes (Asplenium aethiopicum, Asplenium strangeanum and Oleandra distenta) in this same stratum.

- In the herbaceous layer where the height varies between 0.1 and $4 \mathrm{~m}$, the dominant species are Asplenium friesiorum, Cassia mimosoides, Christella gueinitziana, Crotalaria spinosa, Desmodium repandum, Dryopteris klemensis, Polygonum nepalense and Thunbergia mysorensis. There is also a high abundance of vines and weeds (Basella alba and Ipomoea involucrata) in the lower stratum. In a particular way:

- In the forests Edges, there is a dominance of species in two strata (grass and shrub) but in some places, some feet of the Phanerophytes $(6-10 \mathrm{~m}$ high) isolated with a particular role for the succession. 
- In forest windfall we have three strata but with a dominance of herbaceous greenery.

We believe that during the evolution of the floristic composition in these surveys, we distinguish four main phases:

1 st phase "herbaceous" consisting of adventitious vegetation during the period of disturbance,

$2^{\circ}$ phase "herbaceous / shrubs" characterized by large perennial herbs mostly Hemi-cryptophytic 2 to 4 years after period of disturbance,

3rd phase "shrubs / shrubs" with shrubby groups marking the transition between grass groups on the one hand, and forest groups on the other hand after 5 periods of disturbance

4th phase "towards the forest" presenting tree groups marking the transition between the forest groups on the one hand, and the floristic groups (secondary forests) on the other hand after 15-20 periods of disturbance.

\subsection{Effects of environmental parameters on the group}

The links between floristic variability and ecological variability were highlighted by direct gradient analysis. The results obtained show the distribution of the surveys on the first two axes of the CCA (Canonical Correspondence Analysis, Fig.5), the axis 1 seems to evoke the increasing gradient of the recovery of the species and the texture of the soil, the second axis is more correlated with altitudinal effect and slope.

The first two axes account for $61.3 \%$ of the relationship between species and environmental parameters while the speciesenvironment and environmental variables are $71.1 \%$ in axis 2 . In general, the relationships between environmental variables and the floristic variability are very significant (Table 4).

Table 4: Synthetic Presentation of the Results of the Canonical Correspondence Analysis

\begin{tabular}{lllll}
\hline Axes & 1 & 2 & 3 & 4 \\
\hline Eigenvalues : & 0.319 & 0.204 & 0.155 & 0.093 \\
$\begin{array}{l}\text { Species-environment correlations: } \\
\text { Cumulative percentage variance }\end{array}$ & 0.961 & 0.715 & 0.601 & 0.628 \\
$\begin{array}{l}\text { of species data : } \\
\text { of species-environment relation: }\end{array}$ & 31.9 & 52.2 & 67.8 & 77.1 \\
\hline Sum of all eigenvalues : & 1.000 & 61.3 & 69.9 & 75.6 \\
\hline Sum of all canonical eigenvalues : & $71.1 \%$ & & & \\
\hline
\end{tabular}

The ten groups are identifiable on a Dendrogram resulting from the hierarchical ascending classification (Fig.5). This distribution of the surveys on the first two axes of the CCA and the calculations based on the two axes of the CCA of these phytosociological statutes show that the axis 1 seems to evoke the successional gradient with $\mathrm{p}<0.001$ while the disposition of the records of after axis 2 is more correlated with altitude and slope $(\mathrm{p}<0.001)$.

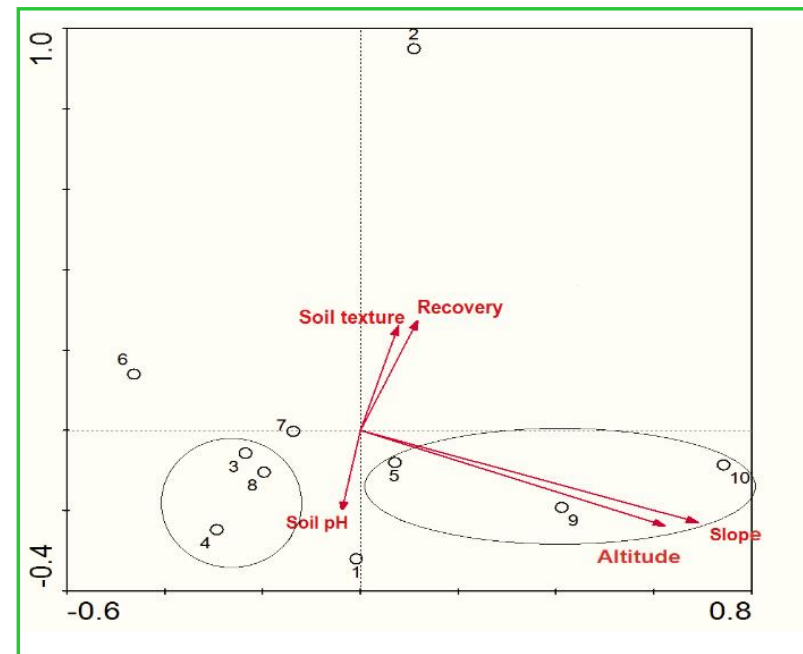

Fig. 5: The Principal Component Analysis Carried Out on the 10 Surveys Carried Out in the Middle and High Altitudes of KBNP with 5 Environmental Variables.
These plant species are sensitive to the availability of nutrients in the soil. In a particular way between the two formations, we have the following situation (Fig. 5):

i) In windfall, species are distributed along the axes according to ecological parameters, such as slope and altitude along the altitudinal gradient, while soil pH influences the species' adaptation to selvedges using the range of acidophilic species with calcicoles. The latter is mainly a function of the nature of the source rock and the nature of the litter and

ii) Canopy cover factors and soil texture are less influential in forest wind and forest Edge.

\section{Discussion}

\subsection{Importance and forests Chablis and Edges in the Albertine Rift}

Forest Edges and Chablis are widespread landscape elements in many Albertine rift regions, due to a long history of forest fragmentation driven by agricultural and urbanization dynamics. The importance of forest Edges for multi-taxa biodiversity has been previously acknowledged, but the mechanisms underlying variations in the direction and magnitude of Edge effects have been seldom explored (Plumptre et al. 2011, Mangambu et al 2017).

The magnitude of Edge effects may increase with the contrast between the forests Chablis and adjacent open habitats and with the degree of landscape fragmentation, forest habitat area and cumulative effects of multiple Edges. Forests Chablis and Edges are a challenge for land management (Vaillancourt 2008). They contain high biodiversity, regulate ecological processes and provide environmental services to agriculture and forestry. Therefore, it is necessary to evaluate and quantify precisely forest's Chablis and Edge influence on vegetation to propose management measures adapted to forest's Chablis and Edge diversity (Whitney 1989; White and Jentsch 2001; Colin et al. 2009).

\subsection{Variation in diversity indices and specific richness in Pteridaie}

Diversity indices are objective criteria for assessing the diversity of a community (Ramade 1994). This phytosociological method, assisted by the software we have used, is intended to constitute coherent assemblages of socioecological groups constituting phytosociological groups (Legendre and Legendre 2012).

The results obtained in this paper show that, despite altitudes, the nature of the soil, textile of the soil and different forest formations, the indices of diversity $\alpha$ are significant and that of $\beta$ show a similarity in the surveys. In particular, the higher values for all these indices were obtained in the surveys carried out in the forest in the windthrow. In addition, it has been found that the overall analysis of species richness is high at the level of the herbaceous layer followed by that of shrub layer in species and in individuals. These results collaborate with those obtained in the eastern dorsal of Lake Kivu by Habiyaremye (1997). The author demonstrates that dominance surveys of Pteridium aquilinum and PteridioPanicetum adenophori Association are rich in the herbaceous and sub-shrub strata.

With regard to the proportion of families, we found respectively that the families Aspleniaceae, Asteraceae, Euphorbiaceae, Fabaceae, Apocynaceae and Rubiaceae are more diverse in species. Almost the same results were found in the bamboo nut of KBNP by Amani et al. (2008) and by Habiyaremye (1997) in the Pteridio-Panicetum adenophori Association at the eastern ridge of Lake Kivu. Both authors recognized the families Rubiaceae, Fabaceae, Lamiaceae, Asteraceae and Poaceae. This floristic resemblance is mainly related to ecological and phytogeographic similarities. According to White (1983) for all tropical Montana forests in Africa, the families of Rubiaceae, Fabaceae, Asteraceae and Poaceae are the most abundant, both in genera and in species. 


\subsection{Proportion of biological traits and phytogeographic distribution}

Regarding the physiognomy of the studied forests and their biological types, the general gross spectrum is dominated by Phanerophytes and in which the Micro-phanerophytes are most diversified in the Pteridium aquilinum group with a gradual decrease of Chamephytes and Geophytes. This can be explained by the "progressive" installation over time of a shrub stratum caused by the decrease of other types (Busmann 2000). Other authors who have worked on succession and vegetation dynamics have made similar conclusions. Donfack (1998) reports that a group of low-rooting annual grasses is indicative of young fallow and forests Edges (1-4 years), that a mixture of annual/perennial and low-growing grasses indicates intermediate fallows (5 to 8 years old) and finally, for old fallows and forest windfalls (9 to 25 years old) or savannahs, it is woody trees that predominate.

This is confirmed by other authors (Yossi and Dembelle 1994; Fournier et al. 2001; Bangirinama 2010). In this way, we find that our results are similar to those obtained by other researchers, such as and Bangiriname et al. (2008) on indicators of post-cultural dynamics of fallow vegetation in the savannah portion of the Kigwena Forest Reserve in the Republic of Burundi and also Tatoni et al. (1998) on the change in the biological distribution of biological types according to a dynamic gradient of colonization of ancient terraces of limestone crops. Tatoni and Roche (1949) give a conclusion in their study that for the other biological spectra in associations or groups with succession such as Therophytes and Chamephytes know a fast decrease whereas the Phanerophytes increase continuously with the installation of ligneous species.

The studies of the phytogeographic distribution show that the majority of species of this group are centers of Afro-Montana endemism, with a dominance of species with an East African mountain distribution, followed by the species proper of mountain. The same results are similar to those obtained by other researchers, such as Bangiriname (2010) and Habiyaremye (1997). In addition, Bangiriname et al. (2008) show that phytogeographic spectra have a large fluctuation of extraterritorial influence, represented by the linkage with Sudano-Zambezian endemic center flora. The results obtained in this work are consistent with those of White (1983 and 1986) who report that the Afromontana flora is remarkably pure with more than $30 \%$ endemic elements and only about $10 \%$ of linkages.

\subsection{Stabilization and dynamics of degraded substrates}

The membership of species in one or the other of the photic categories is really well known only for the forest species, as well at the adult stage as juvenile as the case of the species of the Strombosio-Parinarietea Class and Mitragynetea Class as well as the Polyscietalia fulvae Order. On the other hand, for herbaceous species, with few exceptions, the approach has been simply empirical and proceeds from the comparison of the abundance of individuals of a given species in more or less clear habitats (Wilson and Archer 1979; Fischer and Lindenmayer 2008).

The presence of light at the level of wind throw, would explain the behavior of this species in overgrown undergrowth reaching or exceeding $2.5 \mathrm{~m}$ height (van der Burg 2004).The evolution of the phytosociological groups as a function of time will show the strong presence of sub-mountainous and mountainous ombrophilous species (Strombosio-Parinarietea Class and the FicalhooPodocarpetalia Order) and mountain secondary forest (MusangoTerminalietea Class and the Polyscietalia fulvae Order) which have a major role in replacing this group and ensuring the succession of vegetation. In the undergrowth, dwarfism on the one hand and the architectural model observed on the other hand in certain groups of ferns, such as the genus Dryopteris and Cyathea, constitute adaptation traits in the habitat (Habiyaremye 1997). In some other cases, the same species form a large group with other species, such as the Pteridio-Panicetum adenophori Association at the eastern Lake Kivu Ridge (Habiyaremye 1997). At this level, this association often provides the junction between heathland and pre-forest formations that occupy clearings within rainforests or forests Edges up to $2600 \mathrm{~m}$ altitude.

\subsection{Succession of degraded substrates towards conser- vation and restoration}

Except for the peculiarities of each survey, the dominance sequence of species everywhere has common aspects and mechanisms, resulting in stages with more or less distinct physiognomy in savannah and forest (Van Wagner 1982; Donfack 1998; Foumier 2001). This succession of species is accompanied by that of biological types: Therophytes, Hemi- Cryptophytes, Chamephytes and Phanerophytes. In other words, at the beginning of succession, species such as Therophytes whose traits are associated with the ruderal (rural) tolerant strategy " $\mathrm{R}$ " to disturbances and have a rapid growth, an efficient dispersion and a strong investment in reproduction. In contrast, end-of-succession species are of the Phanerophytes type developing traits associated with the competitive "C" strategy, with slow growth rate, efficient resource utilization and low investment in reproduction (Wenger 1984). Progressive natural recolonization is of interest not only to scientists who wish to better understand the dynamics of plant communities, but also foresters, for the management and development of territories (Mangambu 20016). Variations in the specific composition of plant communities for a given stage can guide the conservation and management of biodiversity at KBNP. Indeed, each successional stage is characterized by groups of sometimes unique and well-defined species that deserve protection for conservation purposes (Mangambu, 2013).

Regarding the restoration in the group Pteridium aquilinum, we note that the species of secondary and primary forests play a very important role in the forest dynamics. At this stage, Montana and sub-montana forest species, secondary forest species and primary indicator forests, which are Phanerophytes, are characteristic of the climax forest stage in the region. Our results corroborate with those of Habiyaremye (1997) and Grime (1979 and 1988).

\section{Conclusion}

This study of the Pteridium aquilinum group in windfall and forests Edges of the KBNP located in a belt of 1478 to $2452 \mathrm{~m}$ above sea level shows that Pteridaie dominate and occur in two forms. In the margins, it is an herbaceous, heliophilic and almost open formation with a reduced number of species. In forest windfall, the density of the constitutive elements of the group is high with three layers. Our initial question was confirmed because the study shows that this Pteridaie group grows to become either a secondary forest or a primary forest.

Rarely can one think that this grouping is modified to become a clearing with various species composed of sub-shrubs and grasses or junctions of the different formations of the forests; primary islets with secondary forests, etc. Therefore, the majority of the formations evolve to diverse forests towards the climax. This study also highlights the major role played by all the trees that are still in the juvenile state and which are less dominant in this group, both in terms of structure and diversity of subsequent tree strata.

This pivotal compartment reflects the level of diversity of tree strata in the KBNP forest in our study portion. Our results, calling into question the earlier theoretical models, provide opportunities for a better understanding of plant distribution patterns in forests Chablis and Edges.

The extension of this study to the entire PNKB can increase other ecological and environmental factors that may contribute to a better understanding of the role that Lycophytes and Ferns play in their integration into various ecosociological groups where they are dominant in this ecosystem that is rich in biodiversity. The complexity of responses obtained warrants to bring more attention to forest's Chablis and Edge diversity for better management and conservation of plant species. 


\section{Acknowledgment}

This article was achieved thanks to the material and financial support granted by the General Direction of Development Cooperation (DGDC) through the Belgian Technical Cooperation (BTC) and Royal Belgian Institute of Natural Sciences "Koninklijk Belgisch Instituut voor"(IRScNB,). We sincerely thank the Director of KBNP for his involvement, his hospitality and support for the field work.

\section{Conflicts of interest}

The authors declare that there is no conflict of interest.

\section{References}

[1] Alignier A (2010), Distribution des communautés végétales sous l'influence des lisières forestières dans des bois fragmentés. Thèse de doctorat, Université de Toulouse/INRA, France.

[2] Amani I, Nyakabwa M \& Lejoly J (2008), Analyse floristique de la forêt de bambous (Sinarundinaria alpina) du Parc National de Kahuzi-Biega. Annales des Sciences de l'Université Officielle de Bukavu $1(1 / 2), 16-27$

[3] APG IV. An update of Angiosperm Phylogeny Group classification for the orders and families of flowering. Botanical Journal of the Linnean Society. 2016; 181: 1-20. https://doi.org/10.1111/boj.12385.

[4] Bangirinama F (2010), Processus de la restauration Eco systémique au cours de la dynamique post-culturale Burundi : mécanismes, caractérisation et séries écologiques. Thèse de doctorat, Université Libre de Bruxelles, Belgique.

[5] Ballard T-M (2000), Impacts of forest management on northern forest soils. Forest Ecology and Management 133, 37-42.

[6] Bangirinama F, Bigendako, M-J \& Lejoly J (2008), Ecologie du paysage et diversité végétale de la zone environnant la forêt de Mpotsa (Burundi). Revue de l'Université du Burundi-Série Sciences Exactes 23,71-89.

[7] Baumann M., Ozdogan M., Kuemmerle T., Wendland K-J., Esipova E. \& Radeloff V-C (2012), Using the Landsat record to detect forest-cover changes during and after the collapse of the Soviet Union in the temperate zone of European Russia. Remote Sensing of Environment, 124, 174-184.

[8] Braize D (1988), Guide des analyses courantes en pédologie. Paris, INERA, 278.

[9] Busmann RW (2000), Vegetation ecology and regeneration of tropical mountain forests. University of Bayreuth, Germany.

[10] Colin F., Vinkler P., Riou-Nivert P., Renaud P., Hervé P., Bock J. \& Piton B (2009). Facteurs de risques de chablis dans les peuplements forestiers: les leçons tirées des tempêtes de 1999 Dans Y. Birot, G. LandmalID et 1. Bonhême (ed.). La Forêt Face aux Tempêtes. Editions Quae, Paris.

[11] De Cáceres M \& Legendre P (2009), Associations between species and groups of sites: indices and statistical inference. Ecology 90 3566-3574. https://doi.org/10.1890/08-1823.1.

[12] De Cáceres M., Legendre P \& Moretti M (2010), Improving indicator species analysis by combining groups of sites. Oikos, 119: 16741684. https://doi.org/10.1111/j.1600-07006.2010.18334x

[13] Donfack P (1998), Végétation des jachères du Nord-Cameroun Typologie, diversité, dynamique, production. Thèse d'état, Université de Yaoundé 1. /Cameroun.

[14] Dufrêne M (2005), Méthodes d'analyse des données écologiques et biogéographiques. Cours de Phytoécologie et cartographie appliquée à l'aménagement des territoires, Université Libre de Bruxelles.

[15] Francis M (2010). Effet du chablis sur la dynamique des peuplements forestiers mixtes. Mémoire de la maîtrise en biologie. Université du Québec /Montréal

[16] Fischer E (1996), Die Vegetation des Parcs National de KahuziBiega, Sud-Kivu, Zaïre. Franz Steiner Verlag. Stuttgart.

[17] Fischer J \& Lindenmayer D (2008), Landscape modification and habitat fragmentation: a synthesis. Global Ecology and Biogeography 16: 265-280. https://doi.org/10.1111/j.1466 8238.2007.00287.x.

[18] Forman RTT (1995), Land mosaics: the ecology of landscape and regions. New York, USA: Cambridge University Press.
[19] Fournier A Floret C, Gnahoua GM (2001). Végétation des jachères et succession postculturale en Afrique tropicale. In: Floret C. \& R Pontanier (éds.) La jachère en Afrique tropicale 2. De la jachère naturelle à la jachère améliorée. Le point des connaissances. IRD/France.

[20] Gnahoua GM. (1998), Analyse phyto-écologique de la flore adventice des cultures post-jachères améliorées en région de forêt semidécidue de Côte-d'Ivoire. DEA, Université Aix- Marseille III/France.

[21] Grime JP (1979), Plant strategies and vegetation processes. John Wiley and Sons, New York.

[22] Grime JP (1988), “The C-S-R model of primary plant strategies Origins, implications and tests". In: Gottlieb L. D. \& S. K. Jain (eds.), Plant evolutionary biology. Chapman and Hall, New York, 371-389.

[23] Habiyaremye M (1997), Etude phytocoenologique de la dorsale orientale de lac Kivu (Rwanda). Annale des Sciences Economique. Vol. 24, Musée Royal de l'Afrique centrale.

[24] Hammer O, Harper, D, Ryan P (2005), PAST: Paleontological Statistics software package for education and data analysis. Paleontologia Electronica 4(1/5): 1-68.

[25] Hicke JA., Allen CD., Desai AR., Dietze M C., Hall R J., Hogg E H. (2012), Effects of biotic disturbances on forest carbon cycling in the United States and Canada. Global Change Biology 18, 7-34.

[26] Hill M-O (1994), DECORANA and TWINSPAN, for ordination and classification of multivariate species data: a new edition, together with supporting programs. In: TABLEFIT programs (ed.) FORTRAN 77, Huntington/ England.

[27] Jacques G \& Christian H (2003), Traitement des données stationnelles (faune), Rebent.

[28] Krebs CJ (1994), Ecology: The experimental analysis of distribution and abundance. HarperCollins: New York

[29] Lebrun J \& Stork A (1991), Enumération des plantes à fleurs d'Afrique tropicale. Conservatoire et Jardin botaniques de la Ville de Genève, Suisse, 1-243

[30] Lebrun J-P \& Stork A-L (1995), Enumération des plantes à fleurs d'Afrique tropicale. Conservatoire et Jardin botaniques de la Ville de Genève, Suisse, 1-341

[31] Lebrun J.-P. \& Stork A-L (1997), Enumération des plantes à fleurs d'Afrique Tropicale. Conservatoire et Jardin botaniques de la Ville de Genève, Genève, Suisse, 1-712

[32] Legendre P \& Legendre L (2010), Numerical ecology, 3rd English edition. Elsevier Science BV, Amsterdam, 853 p

[33] Chown L (1998), Scaling up the value of bioindicators. Trend Ecology and Evolution 13: 46-47. https://doi.org/10.1016/S0169 5347(97)01279-2.

[34] Magurran AE (2004), Measuring biological diversity. Blackwell Publishing company, United Kingdom

[35] Mangambu M., Habiyaremye FM, Lina A, Ntahobavuka H (2010), L'importance du groupement à Cyathea manniana Hook. dans la biodiversité du Parc National de Kahuzi - Biega, R. D. Congo. GeoEco-Trop 34 (1/2), 45-63

[36] Mangambu M, Muhashy H, Janssen T, van Diggelen R, Robbrecht E, Ntahobavuka H (2013), Diversité des Fougères et leurs alliées le long du gradient altitudinal au sein de l'écosystème forestier des montagnes du Parc National de Kahuzi-Biega (R.D CONGO). International Journal of Environmental Studies 70 (2): 259-283. http://dx.doi.org/10.1080/00207233.2013.78007

[37] Mangambu M (2013), Taxonomie, biogéographie et écologie des Ptéridophytes de l'écosystème forestier des montagnes du Parc $\mathrm{Na}$ tional de Kahuzi-Biega à l'Est de la R.D. Congo. Thèse de doctorat, Université d'Anvers/Belgique.

[38] Mangambu M (2016). Diversité, Biogéographie et Ecologie des Ptéridophytes: Cas de massif montagneux du Parc National de Kahuzi - Biega à l'Est de la RD. Congo. Editions Universitaires Européennes.

[39] Mangambu M. \& van Diggelen R (2017), Two New Species of Lox ogramme and Lepisorus (Polypodiaceae): Endemic Ferns from Kivu-Ruwenzori Mountain System (Eastern DR. Congo, Albertine Rift). International Journal of Current Research in Biosciences and Plant Biology 4(4): 61-74. https://doi.org/10.20546/ijcrbp.2017.404.01

[40] Mangambu M., Janssen S., Robbrecht E., Janssen T., Ntahobavuka H. \& Van Ruurd D (2016), A Molecular Investigation of Asplenium: Asplenium kivuensis nov.* - A New Species from Kivu (Democratic Republic of Congo). International Journal of Current Research in Biosciences and Plant Biology, 3(2): 27-37 http://dx.doi.org/10.20546/ijcrbp.2016.302.004

[41] Patterson M-W. \& Yool S.R (1998), Mapping fire-induced vegetation mortality using Landsat Thematic Mapper data: A comparison 
of linear transformation techniques. Remote Sensing of Environment 65, 132-142.

[42] Peltola H., Gardiner B., Kel!omaki S., Kolstrbm T., Lassig R., Moore L., Quine C (2000), Wind and other abiotic risks to forests. Forest Ecology and Management 135: 1-12.

[43] Plumptre A.J, Kujirakwinja D., Rwetsiba A.., Wanyama F., Nangendo G., Fuller R. \& Possingham H (2011). The Distribution of Landscape Species in the Greater Virunga Landscape: Conservation implications. Rapport the Wild life Conservation Society. Australia, University Of Queensland. http://www.wcs.org.

[44] Pteridophyte Phylogeny Group (2016), A community-derived classification for extant lycophytes and ferns (Institute of Botany, Chinese Academy of Sciences). Journal of Systematics and Evolution 54 (6): 563-603 http://dx.doi.org/ 10.1111/jse.12229

[45] Pichi-Sermolli R (1985). A contribution to the knowledge of the Pteridophyta of Rwanda, Burundi, and Kivu (Zaire) II. Bulletin du Jardin Botanique National de Belgique 55: 123-206. https://doi.org/10.2307/3668014.

[46] Ramade F (1994), Eléments d'écologie, écologie fondamentale. Ediscience International/Paris.

[47] Roux JP (2009), Synopsi of the Lycodiopyta and Pteridophyta of Africa, Madagascar and neighbouring islands. Strelitzia 23. South African National Biodiversity Institute, Pretoria.

[48] Senterre B (2005), Recherches méthodologiques pour la typologie de la végétation et la phytogéographie des forêts denses d'Afrique tropicale. Thèse de doctorat, Université Libre de Bruxelles/Belgique

[49] Serpantié G \& Devineau J L (1991), Le programme "interrelations systèmes écologiques systèmes de culture en zone soudanienne (ouest-burkinabé)" : projet scientifique. In: Floret C. \& G. Serpantié (éds.), La jachère en Afrique de l'Ouest. Colloques et Séminaires, ORSTOM, 481-490.

[50] Stehman SV (2012), Impact of sample size allocation when using stratified random sampling to estimate accuracy and area of landcover change. Remote Sensing Letters. 3, 111-120.

[51] Taton A (1949), Les principales associations herbeuses de la région de Nioka et leur valeur agrostologique. Conférence africaine des sols. Goma. Bulletin du Jardin Botanique National de Belgique 40, 1884-1901

[52] Tatoni T \& Roche P (1994), Comparison of old-field and forest revegetation dynamics in Provence. Journal of Vegetation Science 5 , 295-302. https://doi.org/10.2307/3235852.

[53] Ter Braak CJF \& Šmilauer P (2002). CANOCO Reference Manual and CanoDraw for Windows User's Guide: Software for Canonical Community Ordination (version 4.5). Ithaca, New York, USA (www.canoco.com): Microcomputer Power.

[54] Van der Burg W (2004), Pteridium aquilinum (L.) Kuhn, Fiche de Protobase. Grubben, G.J.H.et Denton, O.A. (Editeurs). Prota (Plant Resources of Tropical Africa/Ressources végétales de l'Afrique Tropicale), Wageningen/Pays Bas, 36-39

[55] Vaillancourt M.-A (2008). Effets des régimes de perturbation par le chablis sur la biodiversité et les implications pour la récupération. Ministère des Ressources naturelles et de la faune, Québec.

[56] Vaillancourt M-A., De Grandpré L., Gauthier S., Leduc A., Kneeshaw O., Claveau Y. \& Bergeron Y. (2008), Comment les perturbations naturelles peuventelles constituer un guide pour l'aménagement forestier écosystémique Dans S. Gauthier, M.-A. Vaillancourt, A. Leduc et al. (ed.). Aménagement Écosystémique de la Forêt Boréale. Presses de l'Université du Québec, Qc. 16: 62-84

[57] Van Wagner C. (1982). Practical aspects of the line intersect method, Information Report PI-X-I2. Petawawa National Forestry Institute, Canadian Forestry Service, Chalk River, Ontario, Canada.

[58] Webster G.L. (1995), The Panorama of Neotropical Cloud Forest. Dans: Churchill S. (Eds.): Biodiversity and Conservation of Neotropical Montane Forests, 53-77.

[59] Wenger K F. (1984). Forestry Handbook. John Wiley \& Sons, Inc., New York.

[60] White F (1983). The Vegetation of Africa. A descriptive Memoire to Accompany the UNESCO/AETFAT Vegetation Map of Africa. UNESCO, Paris, UNESCO/ AETFAT.

[61] White PS. (1979), Pattern, process, and natural disturbance in vegetation. Botanical Review 45:229-299.

[62] White F (1986), La végétation de l'Afrique. Mémoire accompagnant la carte de végétation de l'Afrique UNESCO/AETFAT/UNSO. ORSTOM et UNESCO. Paris, collection. Recherches sur les Ressources Naturelles 20: 1-384

[63] White PS. \& Jentsch A (2001), The search for generality in studies of disturbance and ecosystem dynamics. Progress in Botany $62: 399-450$
[64] Whitney RD (1989), Root rot damage in naturally regenerated stands of spruce and balsam fir in Ontario. Canadian Journal of Forest Research 19:295-308.

[65] Wulder M., Masek J., Cohen W, Loveland R. \& Woodcock C (2012), Opening the archive: How free data has enabled the science and monitoring promise of Landsat. Remote Sensing of Environment $122,2-10$.

[66] Wilson BF. \& Archer RR (1979), Tree design: some biological solutions to mechanical problems. BioScience 293-298.

[67] Yossi H., Dembele F (1993). Dynamique de la végétation postculturale et des lisiers en zone soudanienne au Mali : évolution de la composition floristique et de la strate ligneuse. In: Floret C. \& G. Serpantié (éds.), La jachère en Afrique de l'Ouest. Collection Colloques et Séminaires, ORSTOM, Paris, 341-350. 